\title{
The Singer or the Song? Developments in Performers' Rights from the Perspective of a Cultural Economist
}

\author{
RUTH TOWSE* \\ Erasmus University Rotterdam
}

Over the last century, performers gradually acquired statutory protection of their economic and moral rights. These rights are not copyright in the legal sense but neighboring rights and until recently, they were mainly remuneration rights that are collectively administered. With the WPPT (WIPO Performers and Phonograms Treaty), performers now have individual exclusive rights for digital performances; this leads to the question: what has motivated this change - is it a change in the perception of the value of performer or a change brought about by the changing technology of copying or, indeed, a change that reflects different economic costs and benefits? The paper discusses the role of copyright law as an incentive to performers and asks if the economic role of the performer is so different from that of the author. The conclusion is that a complex interaction of the legal regulations, economic conditions and institutional arrangements for administering these new rights will determine the outcome.

\section{INTRODUCTION}

To an economist interested in artists' labor markets, the distinction between the creative artist's copyright and the performing artist's rights neighboring on copyright is somewhat puzzling, the more so as in the music industry (the industry in which neighboring rights have so far predominated), the singersongwriter enjoys both sets of rights - the copyright (or author's right) for the composition of the song and the performer's right for its performance. The very little empirical evidence there is on the subject does not suggest that the

${ }^{*}$ Forerunners of this paper were presented at the AHRB Copyright Research Network Conference held at Birkbeck College, University of London, held in June 2004 and at the SERCI annual conference in Torino, Italy in July, 2004. I am extremely grateful to the referee of this paper for such stimulating comments on the earlier version of this paper, which was thoroughly revised thanks to his or her remarks. Contact: towse@fhk.eur.nl 
author's right is more valuable than the performer's neighboring right. Indeed, neither earns much from either set of rights unless he or she belongs to the ethereal ranks of the superstar (Towse, 2001a).

I believe that the rationale for this distinction is strongly influenced by our cultural history with the prevalence of the Romantic view of the author creating original work as a sort of sacred activity, while the performer merely reproduces the work in performance as a sort of administrator or executive. This view is still touted in standard works on the social psychology of creativity. It implicitly ranks 'creativity' above 'talent' in the artistic pantheon; to an economist that is the equivalent of saying production is more important than marketing - in fact, each needs the other for getting the 'product' to the market. Still, it is nevertheless worthwhile to ask if there is also an underlying economic rationale. If we believe that copyright law (or any other law) can be justified in economic terms, then the lesser rights of the performer must be explicable in terms of a fundamental economic distinction between performers and creators. Moreover, now that performers have been awarded some rights that make them more or less on a par with creators, we should ask what underlying economic change has taken place to justify the legal change of heart, otherwise that change has to be explained on different grounds, for example, a change in the socio-cultural status of performers. I shall discuss this question here using the examples of composers and singers.

\section{A BRIEF ECONOMIC HISTORY OF MUSIC AND PERFORMERS' RIGHTS}

It is often said that a crucial economic distinction between composer and singer is that the latter can be paid on the spot for his performance whereas the composer has to be rewarded for the (multiple) uses of her work. However, there is no hard and fast economic 'upstream/downstream rule' here; historically, the star performer (the castrato or the prima donna in opera) dictated terms to the composer (witness the plot of Richard Strauss's opera Ariadne anf Naxos). Indeed, the Mozart concert arias (nowadays considered sublime examples of his genius) were commissioned by the singer to show off her voice to its best advantage and she thought nothing of inserting them at will into the opera at hand, even while the original composer was conducting it! In other words, the far more highly rated singer paid the much less well-known composer a flat fee for the work rather than the reverse situation, which apparently is the one envisaged by modern copyright lawyers.

What is historically the case, though, is that apart from the 'chosen few' superstars, the occupation of performer - whether singer, musician or actor -

Review of Law \& Economics, ( 2007 by bepress 
was held in very low esteem in the $18^{\text {th }}$ and $19^{\text {th }}$ centuries. Theatres and opera houses were regarded as dens of potential insurgency (hence the continued presence of the carabinieri at La Scala Milan and the former activities of the Lord Chamberlain in England) and female performers were regarded as little better than prostitutes, which sadly some became in order to survive on the poor pay of the chorus. Singers' contracts in the Italian opera houses made frequent reference to restraining their 'disorderly' behavior and they were imprisoned for breach of contract (including, by the way, for not giving a better performance! - see Christiansen, 1984). ${ }^{\text {' }}$

The $18^{\text {th }}$ century economist Adam Smith held a view fairly typical for his day of the performer's talent:

"There are some very beautiful and agreeable talents of which the possession commands a certain sort of admiration; but of which the exercise for the sake of gain is considered, whether from reason or prejudice, as a sort of public prostitution. The pecuniary recompense therefore of those who exercise them in this manner, must be sufficient, not only to pay for the time, labor and expense of acquiring the talents, but for the discredit which attends the employment of them as a means of subsistence. The exorbitant rewards of players, opera-singers, operadancers, etc. are founded upon those two principles; the rarity and beauty of the talents, and the discredit of employing them in this manner.......Such talents, though far from being common, are by no means so rare as is imagined. Many people possess them in great perfection, who disdain to make use of them; and many more are capable of acquiring them, if any thing could be made honorably by them" (Adam Smith, 1776, The Wealth of Nations, Book I, Chapter X, Part I, ed. Cannan; 108-9).

Smith thus explained the high payments to performers as a compensation payment for the non pecuniary disadvantage of the occupation of performer, resulting in a shortage of supply. It seems not unlikely that the architects of copyright law shared this view of performers both in England, where musical compositions came within the scope of copyright at exactly the time at which Smith was writing, and later on in France, Germany (Prussia) and Italy.

Moreover, to pursue the economic history of musical performance a little further, the distinction between the professions of composer and performer only developed slowly. Until the end of the $18^{\text {th }}$ century, not only did most composers perform or conduct their own works (even as late as Brahms, the composer had

\footnotetext{
${ }^{1}$ Contracts included a ban on spitting on stage and relieving oneself at the back of the stage! (Rosselli, 1984).
} 
to make his name as a pianist, as Beethoven, Mozart and a host of others had done before him), they also were treated by their patrons as servants (Wagner had to wear servants' livery while at the court of Weimar in the 1840s). In opera, which in the $18^{\text {th }}$ and $19^{\text {th }}$ centuries was the most popular form of entertainment and offered the most lucrative work for composers and performers, the composer only slowly emerged as the 'name' attached to the work. Mozart's operas were not advertised in his day using his name but rather the name of the poet who wrote the libretto - Metastasio or da Ponte (as in 'da Ponte's Don Giovanni'). Thus the primacy of the composer as the author to be endowed with copyright only really established itself in the late $19^{\text {th }}$ century - the higher status of the composer no doubt being assisted precisely by that grant of rights.

Composers, however, were always vulnerable to unauthorized copying of their works whereas performers were not until relatively recently. This is no doubt an economic rationale for their different treatment under copyright law before the advent of sound recording. The evolution of copyright law is connected to the technologies for making copies, starting with printing and on through to MP3 and P2P. The inventions of sound recording and of radio had mixed outcomes for the music profession: composers were able to reach far larger audiences while performers experienced a considerable fall in the demand for their services. Musical performance in the $20^{\text {th }}$ century began with a high level of demand for live music played by bands, ensembles and orchestras everywhere from parks to tearooms, which fell throughout the century so that by the end the number of musicians was about quarter of what it had been at the beginning (Ehrlich, 1985). Nowadays, by contrast, every hotel, disco, sports hall and shop plays recorded music that can be produced by employing one group of performers in a one-off recording session.

The effect of 'canned' music on the employment of musicians in the UK was countered by several moves: one was getting the BBC agree to restrict 'needle time' and to play so many hours of live music; another was to get compensation for the loss of income from live work via rights to remuneration in copyright law. Thus began the development of performers' rights but they were only rights neighboring on copyright, not copyright per se, and were collective remuneration rights, not individual exclusive rights. Performers were treated differently in legal terms from composers even though their services are mostly jointly marketed for economic reasons and their rights exercised side by side. Therefore we need to ask what is the underlying economic logic that determines whether or not the individual artist (singer or song-writer) gets a royalty payment or remuneration as compensation for the use of her work. Does this depend upon the way the good or service gets to market or upon the

Review of Law \& Economics, ( 2007 by bepress 
legal distinction between the exclusive copyright for authors and the right to remuneration as merely a related right?

With the advent of the WIPO Performers and Phonograms Treaty (WPPT), signed in 1996 and now incorporated into most national copyright laws, this distinction has changed as performers acquire individual exclusive rights in their digital performances. The point of this paper is to discuss the economic implications of this change. If there was indeed an economic logic for the differential legal treatment of composers and performers under copyright law before, what has changed that? Or is it that we now view the performer's talent as being equivalent to the author's creativity and copyright law reflects a new respect for performers?

The paper begins by sketching the development and economics of performers' rights and then discusses the payment arrangements in markets in the cultural sector. There follow sections contrasting the exercise of individual rights on the open market with the collective administration and the effect of DRM (digital rights management) is considered. Finally, there is a discussion of how effective copyright law is as an incentive to the supply of cultural products, linked to the question how economists (especially cultural economists) evaluate such changes in law.

\section{DEVELOPMENT OF PERFORMERS' RIGHTS}

The story of performers' rights essentially begins with the 1961 Rome Convention on neighboring rights, which forms the basis of national laws and also forms the basis for the WPPT. Performers previously had some rights; to give the example of the UK, in 1925, performers acquired the right to control the fixation and use of their performances (mainly in sound recordings). However, it was only in 1988 that musical performers ${ }^{2}$ in the UK acquired the right to control recording of live performances and in 1996 that they acquired fully assignable property rights and individual rights to remuneration (before that, remuneration had been paid collectively to the Musicians' Union but not distributed on an individual basis: see Towse, 2001a). Protection lasts 50 years from the date of fixation.

Rights to remuneration are essentially compensation for compulsory licenses that override the general principle of copyright that the author/creator has the exclusive right to control exploitation of his or her work (Gallagher, 2002). In the case of sound recordings, what this means in practice is that once a

\footnotetext{
2 Audio visual performers, such as film actors, were not included in this legislation. There is now talk of their acquiring copyright protection.
} 
performer has contracted with a record label to make a sound recording, she has no further control over its exploitation (e.g. by public performance) but she receives payment for these uses. Her rights are exhausted upon the first fixation of her performance. In this the law obeys economic logic in preventing hold-ups. ${ }^{3}$ However, it leaves the record label holding all the important decision rights, including whether or not to keep the work in the catalogue.

In the world of the performing arts, a significant distinction is made between the star and lead performers ('principals'), the 'named' performers and the 'nameless' chorus, walk-on players and suchlike. In live performance, the principal performers are often paid on a different basis: they receive fees and/or incentive payments, such as a share of box office revenues, while the other performers are paid a weekly wage. This distinction carries over into contracts in the recorded media. In the music industry, the distinction is between the 'contracted' or 'featured' artists and the 'backing' or 'non-featured' artists - the members of the orchestra or backing musicians and singers. The former have individual royalty contracts based on sales and the latter are paid a flat spot fee at the time of the recording (a studio fee) with no future payment from sales. Featured artists with royalty contracts must therefore maintain contact with the record label that recorded their work, whereas non-featured ones do not need to do so and for a long time, there was no mechanism for tracing their contribution to a sound recording.

In 1992, the so-called EC Rental Directive ${ }^{4}$ was drawn up, which basically enforced the Rome Convention for all EU countries. Its drafters evidently believed that one of the roles of copyright and related rights legislation was to correct the weaker bargaining position of the non-featured performers and that the way to do this was to require that equitable remuneration could only be administered by a collecting society set up for that purpose. ${ }^{5}$ This is one of perhaps many examples where the law has been used in the attempt to 'correct' perceived market failure for equity rather than efficiency reasons. ${ }^{6}$

The WIPO Treaties, the so-called 'Internet Treaties', the 1996 WIPO Copyright Treaty (WCT) and the WIPO Performances and Phonograms Treaty (WPPT) have made important changes to performers' rights introducing a new

\footnotetext{
${ }^{3}$ That may also be said of composers and sound recordings; for example, a composer cannot control further recordings of his work after giving permission for the first sound recording.

${ }^{4}$ Council Directive 'on rental and lending rights and on certain rights related to copyright in the field of intellectual property' (EC Directive, 1992).

${ }^{5}$ See Reinbothe and Lewinski (1993).

${ }^{6}$ However, in so doing, it risked creating a situation in which the increased transaction costs to users threaten to swamp any benefits (see Towse, 2001a).
}

Review of Law \& Economics, (C) 2007 by bepress 
The Singer or the Song? / 751

exclusive right in favor of copyright owners, including performers, who make their works available on-line to the public (known as the 'making available right'). They also mandate the prohibition of the circumvention of copyright protection (TPMs - technological protection measures) and of tampering with rights management information (DRM - digital rights management). The European Union signed these WIPO Treaties on behalf of member states and subsequently issued Directive 2001/29/EC on the harmonization of certain aspects of copyright and related rights in the information society, the so-called 'Copyright Directive,' finalized in 2001, which required member states to reform their national copyright laws where necessary to comply with the Directive. In the USA, the Digital Millennium Copyright Act (DMCA) implements the WIPO Treaties. Thus with the WPPT, performers now have an individual exclusive right (though not a full copyright) equivalent to that of authors.

This change to the rights and, one might say, status of performers raises several questions that are discussed below: What is the economic justification for this change to performers' rights? What difference could the grant of the exclusive right make to the bargaining power and therefore to the incomes of performers who already had assignable property rights? How can the individual performer's right be exercised?

\section{ECONOMICS OF PERFORMERS' RIGHTS}

The economic aim of copyright law is held to be that it offers an incentive to create works of art, literature, music and so on, so we may reasonably assume that this aim applies to changes in the law too: the change should improve the incentive. The standard economic rationale for protection from copying is that once a work has been put in fixed form, it can be copied and so is vulnerable to free-riding. Without 'privatization' by statutorily created property rights, the creator would not be able to charge a price high enough to cover the fixed cost of creating the work because a copier would only have to incur the marginal cost of making a copy. Moreover, the copier can avoid the risk of failure that the first publisher has to take and so does not have to charge a risk premium in the price. An unauthorized copier can therefore supply the market at a price reflecting the marginal cost that does not cover the fixed cost or the risk premium and that price necessarily undercuts the original creator, thus decreasing (or destroying) the incentive to create and distribute works of art.

\footnotetext{
7 These are only the economic implications. Performers now also acquire moral rights. The question whether moral rights have economic impact has been considered (see Rushton, 1998) for a summary of the arguments).
} 
So, the first criterion for judging copyright reform must be: does it stimulate greater creativity (always remembering that this is a question of marginal changes to incentives)? That raises difficult fundamental problems about artistic motivation that few economists (and, I suspect, fewer lawyers) have so far grappled with. These are dealt with in more detail below.

Can the same rationale be applied to performers? Performers are identified in UK copyright law as persons who have rights in their performances. A performance is formed by talent, years of training and investment in human capital and involves considerable risk of how it will be received by audiences. A performance is a work in the sense of copyright law and so the same economic logic should apply as to the work of an author, that is that the exclusive right to control the exploitation of the performance is the incentive to its realization. However, the difference is that the performance, while a work in its own right, cannot be separated from the work being performed. The received view is that when performers perform a work created by an author - say an existing song already written by a composer - their performance is already propertized by copyright law. So from a purely microeconomic perspective, once an initial IP is granted to the original creation, there is no need to intervene by granting other property rights on the same derivative product and the performer is only able to produce her performance on license from the composer. Thus the law reflects the primacy of the author over the performer. I dispute this view, however, because it fails to take into account how markets work in the cultural sector and the matter of value-added. It is in fact a profoundly uneconomic approach to the performer's right issue and ignores the need to bundle works and rights in order to get a product such as a CD to market.

It is logically true, of course, that the song can exist without the singer but the singer cannot perform without the song. However, it should perhaps be pointed out that there are far, far, more songs and other musical works in existence than will ever be performed - a problem dubbed by cultural economists the 'Malthusian nightmare for composers' (O'Hare, 1980). Thus incentives to perform must be taken into account if copyright is to achieve its goal of not only stimulating the creation of works but also their publication. The unperformed song has little value either to the composer or to society at large. The question, then, is about the value-added by the singer to the song. The performance, even by some amateur singer in the local church hall, adds value by causing the song to become better known than it would be if were left sitting on the composer's piano. A performance by a superstar would greatly enhance the value of the song, even leading to a situation in which the singer earns far more than the composer. Now in such a case, Coase would tell us that the singer should own the song not the composer, unless transaction costs

Review of Law \& Economics, ( 2007 by bepress 
The Singer or the Song? / 753

are prohibitive - and why should they be for a simple sale? Indeed, if a singer makes a song famous, so that it is purchased in sheet music (as in days of old) or made into cover versions, singer should have a share in that but she does not. ${ }^{8}$ Even with new performers' rights, the 'external' benefit accrues to the composer, who cannot have anticipated (in most cases) that the star singer would offer such a bounty. In fact, the Mozart concert aria situation quoted earlier perfectly obeyed Coasean logic - the singer commissioned, and therefore owned, the song.

Thus economic logic does not support the primacy of the composer in general unless the case can be made that transaction costs would always be greater if the property rights in the song as well as in its performance were allocated to the singer rather than to the composer. One might argue that those costs as identified, for example, by Landes and Posner (1989) - the cost of tracing owners and clearing rights - could well be lower when the composer owns the song because (potential) performers are many but there is only one composer of any given song. Still, transaction costs would be even lower or non-existent if the singer bought the song. What happens in practice is that the singer obtains the right to perform the song via the publisher of the music.

This model, however, is oversimplified because it is cast in terms of a song (musical work) and one singer. Often, there are many performers involved in a performance, some who are featured performers but many who are not. It is often argued that the stars, the featured artists, always could reap their rewards via market mechanisms, such as the contractual arrangement with the theatrical producer or sound recording maker (the record label). A box office share or royalty contract ensures that the singer gets her portion of the success or otherwise of the music being performed. But what of the non-featured performers - the backing artists, such as orchestral players or singers? In their case, the view always expressed in the USA (which has not signed the Rome Convention) is that there is no justification for them to have an incentive contract because they do not add any value to the protected work (the song). One should therefore ask why they deserve IP (in addition to the pay they get for the work), the standard US view. ${ }^{9}$ Apart from the misunderstanding about

\footnotetext{
${ }^{8}$ It used to be common practice for music publishers to publish collections of songs with the name of a famous singer on them - 'Nellie Melba's Favourite Songs' or some such. Coase (1979) gives many examples of the performers obtaining payments for performing certain songs in his famous 'payola' article.

${ }^{9}$ In the USA, performers have not been entitled to remuneration because the view was taken that radio play acted as advertising and therefore stimulated sales. This is, of course, reminiscent of the discussion about the relation between downloading music and CD sales. The DMCA now recognizes performers' rights for public performance of digitally produced music.
} 
the real world payment arrangements for a lot of recording work by session performers ${ }^{10}$, again we get to the question: how can a choral work acquire value without a chorus or an orchestral work without orchestral players or either without the conductor?

If a performer adds value, she should be entitled (by Lockean principle and also according to marginal productivity theory) to share in the revenue from the performance of the work. Performers' time has an alternative cost and unless they are rewarded accordingly, there is little (or less) incentive for performers to spend their time making recordings or other such work. Even if the performer were already on salary with an orchestra or chorus, economic efficiency requires that their pay reflect the revenues received by the organization employing them. Of course, if they receive payment through other means, e.g. royalties, then economists would expect that the 'spot' pay for work (fees or salary) would be reduced to take into account the future royalty or remuneration payment. ${ }^{11}$

\section{PAYMENT ARRANGEMENTS FOR PERFORMERS' RIGHTS}

Having established the economic case for performers' remuneration, we turn to the question of how payments are made in the different markets in which their performances are supplied.

A feature of many copiable works, such as sound recordings, is that they can simultaneously serve two markets, the 'primary' market of sales to end users and the 'secondary' market, in which the product is reused for intermediate commercial purposes or by private users. In the 'analogue' world, primary and secondary markets were distinct and called for separate arrangements for paying performers. These arrangements are described below. The supply of digitalized music via the Internet, however, has necessitated new payment arrangements, such as short-term license fees, and has blurred the distinction between intermediate and end consumer.

\footnotetext{
10 There is a free and highly organized market in the services of professional performers who are available by the session (usually 3 hours) for live and recording work of all kinds in various places, London being one of the main ones. You can make up a choir or get backing singers via agencies and diary services at very short notice - even a day (see Towse, 1993).

${ }^{11}$ See Watt and Towse (2006) for an analysis of this trade-off.
}

Review of Law \& Economics, ( 2007 by bepress 
The Singer or the Song? / 755

\subsection{INDIVIDUAL CONTRACTS IN PRIMARY MARKETS}

Featured performers are paid for sales in the primary market through the contract they make with the producer of the sound recording, which is typically a royalty contract that pays the performer $10-15 \%$ of the sales price (Caves, 2000).

The theory of economic organization can be evoked here to offer insight into these payment arrangements; both transaction cost and property rights approaches to contract theory shed light on them. The purpose of the contract is to obtain the maximum benefit for each party from the allocation of rights. In order to achieve that goal, suitable incentives have to be offered to each, subject to the transaction costs of writing the contract and enforcing it. With a royalty contract, the performer shares the risk with the publisher (record label) and therefore stands to gain or lose from the works' success on the market, including any revival in its sales stimulated by the same performer's later work, thus giving the performer the incentive to produce consistently high quality works. The record label can exploit that by tying in the performer with an option contract on future work (Caves, 2000). In the case of featured (contracted) performers, a variety of payment arrangements is possible, ranging from one-off spot fee payments that buy-out rights to a 'pure royalty' contract with no advance payment and little concession of rights (Towse, 2003). Each arrangement offers different incentives to the performer in terms of risk bearing and delivery of quality of work (Towse, 1999). Watt (2000) makes a particular contribution to the economics of copyright by his analysis of intermediate contracts. Specifically, he points out that it is difficult to see why authors always insist upon sharing risk when an outright sale would be financially more beneficial. ${ }^{12}$ This same argument applies to performers with individual exclusive rights.

This economic approach has been dismissed by Cornish (2003), however, on the grounds that the underlying assumption of rational economic behavior is 'unrealistic'. Then, as so often happens, he immediately substitutes his own favored theory of incentives! - that artists are led on by 'undue optimism' (what Adam Smith had already in 1776 called: "the contempt of risk and the presumptuous hope of success....." Wealth of Nations, Vol. 1, Bk. 1, Chap. X). Taken as a whole, Cornish's argument is that the courts have taken a reliable stand in the interpretation of contractual phrases such as 'reasonable' remuneration. Therefore, the creator can carry on creating safe in the knowledge that the courts will protect her. That seems an extraordinary stance to take, on the one hand because a good contract should avoid terms that are

\footnotetext{
12 I have also thought hard about this question and concluded that one explanation for seemingly irrational behavior lies in the radical uncertainty (extreme bounded rationality) of markets in the arts (Towse, 1999).
} 
so obviously open to dispute and, on the other, because the transaction costs of going to court are a deadweight loss that should be avoided.

\subsection{PAYMENT ARRANGEMENTS IN THE SECONDARY MARKET VIA COLLECTING SOCIETIES}

Payment for use of copyright works in the secondary market is organized through collecting societies. For performers, these payments are equitable remuneration for public performance. Collecting societies carry out the task of issuing licenses to users on behalf of rights owners on a collective rather than on an individual basis, pooling the transaction costs of licensing, monitoring use and distributing payments to members, for whom the costs would otherwise be too high to allow them to exercise their rights individually. The minimization of transaction costs leads to a form of licensing that distorts the individual performer's incentive and reward: the so-called 'blanket' license used by collecting societies is in fact an early form of 'one-stop-shop' licensing that grants permission to the licensee by means of one transaction, allowing the use of any work in the repertoire of all the societies' members, as well as that of affiliate societies in other countries, meaning effectively almost the whole world repertoire. The blanket license fee cannot be differentiated according to the popularity of the performer, resulting in cross-subsidy within the collecting society, though this distortion is countered by the rules for distribution of income to members, which do take into account the amount of use made of individual works.

Generalization about collecting societies is complicated by the fact that their governance is very different in different countries. Many were set up in the first place under a state grant of monopoly and are a sort of state agency. ${ }^{13}$ Moreover, in some countries, licensing rates are set by a court or Copyright Board, removing the process from the market (Einhorn, 2003). Another matter is who actually pays the costs of these arrangements: some administrative costs are paid by the rights holders but users may also have considerable costs imposed on them, e.g. logging the play of each CD track. However, in some countries, the state bears the administrative costs.

Of course, the more performers there are involved in a performance, the greater transaction costs are likely to be. This may indeed have been the motive under in the Rental Directive for requiring remuneration to non-featured performers for public performance of sound recordings to be paid to a collecting society designated for that purpose (though it ignored the

\footnotetext{
13 That is not the case in the UK, where the collecting societies are private co-operatives, though the Copyright Tribunal has jurisdiction in case of disputes.
}

Review of Law \& Economics, ( 2007 by bepress 
considerable costs of setting up such an organization in the first instance). The fact that administration of the right was collective meant that ensembles had to register as entities, though distribution was to the individual based on her contribution to the performance. This meant that orchestral and chorus managers, and those of other ensembles in classical, jazz and popular music of all kinds, had the task of dividing the spoils, while the collecting society distributed to the ensemble based on its contribution to the society's revenue; thus the collecting society passed on some of the transaction costs to the coordinator of the ensemble. ${ }^{14}$ With the introduction of the individual right, this cost has now been passed back to the collecting society. ${ }^{15}$

\section{EXERCISING INDIVIDUAL EXCLUSIVE PERFORMERS' RIGHTS}

Following the WPPT and the subsequent EU Information Society Directive, all performers, featured and non-featured, have individual exclusive rights for making available their recordings (audio and audiovisual) to the public in such a way that of the public may access them from a place and at a time chosen by them. ${ }^{16}$ (It is worth noting that remuneration for public performances of recordings that have not been digitalized will continue to be administered as before, though possibly using DRM). With an exclusive right, the performer can negotiate an individual bargain with a user: let's say, a singer doing a studio recording as a 'backing artist'. Before the grant of the individual right, she was paid a fee for the recording under a standard contract that bought out her rights and, following the Rental Directive, was entitled to equitable remuneration for public performance of the sound recording according to her individual contribution to the recording as measured on a track-by-track basis. The remuneration would have been paid by the relevant collecting society (in the UK by the Performing Arts Media Rights Association, PAMRA) from its public performance license fee paid by all users who play recorded music in public, the fee having been negotiated by PAMRA with industry representative bodies. The singer would report to PAMRA what tracks of which recording

\footnotetext{
${ }^{14}$ In practice, many orchestral and choral contracts offer a fixed rate of compensation to their members for giving up their copyright entitlements. Such contracts are typically negotiated by collective bargaining (see Sand, 2003).

15 In the three year interval between writing this article and its publication, two detailed surveys of the economics of collecting societies have been published (Towse, 2006, and Towse and Handke, 2006)

${ }^{16}$ An interesting research project would be to look at how this is introduced in the USA where performers have recently acquired rights in public performance for the first time.
} 
she played on (or believed she did as recording engineers decide the final use of takes). PAMRA would then apply its 'playlist' and calculate the payment due to the singer and distribute it to her or her heirs (the right applies for a period of 50 years from the year in which the recording was made).

What of this scenario changes with the creation of an individual exclusive right? It is claimed that it strengthens the performer's bargaining position. The performer now can negotiate her individual royalty, rate of payment and the terms of her contract with the record label. In the UK (and no doubt elsewhere too), however, the contract would typically be a standard one collectively agreed by her trade union: contracting is an expensive procedure and it is almost certain that for such an item as a recording session (that is usually a 3 hour one-off contract) there is a standard contract and standard payment, for example, in the UK negotiated between the Musicians' Union (or PAMRA) and the recording industry, and this enables the market to work with low transaction costs. We can therefore expect that that practice will continue even with individual rights. However, individual negotiation in an over-crowded market (many performers and a few record labels) could easily lead to undercutting the negotiated rate. It is worthwhile noting at this point that UK and US performers managed their affairs in the 1970s and 80s by strong trade unionization that more or less prevented cut-throat competition without the aid of copyright law (Sand, 2003). This is in contrast to the reliance on the part of performers, especially non-featured ones, in other European countries on neighboring rights to enable them to obtain income in the form of collectively negotiated remuneration. Even so, surveys of performers' earnings have shown that few earned above the minimum rate of pay for 'live' work and the little evidence there is shows that they typically earn little from copyright sources either (Kretschmer, 2005; Towse, 2001a)

Of course, collective bargaining of rates of pay to performers (or any other kind of worker) is not always viewed with favor by those who would hire their services. As we have seen, the economic justification of collective rights management (CRM) is that individual authors and performers would not be able to effectively exercise their rights without it. It is perhaps worth noting that the record industry was willing to see the new performers' rights under WPPT introduced but only on condition that they were made waivable (note that the Rental Directive rights were specifically made unwaivable). However, it is conceivable that individual waivable rights could put non-star performers in a more vulnerable economic position rather than strengthening it, as claimed. Getting rid of collective action opens the door to the possibility to 'divide and

Review of Law \& Economics, ( 92007 by bepress 
The Singer or the Song? / 759

rule. ${ }^{17}$ It is perhaps not only in a spirit of egalitarianism, then, that the record industry agreed to the introduction of exclusive rights for performers.

These doubts raise two questions: on what basis can it be said that an individual exclusive right is preferable to a collective right to remuneration for a performer? For an economist, the judgment would rest on two basic issues: first, what is the aim of the policy? - in this case, what is the point of the change in the law on performers' rights? Second, what are the costs and benefits of the proposed change? Together they provide the basis for a evaluating a welfare improvement. We can then also ask the question whether alternative policies could not also achieve the same goal.

\section{IS THE INTRODUCTION OF THE EXCLUSIVE RIGHT FOR PERFORMERS A WELFARE IMPROVEMENT?}

In order to answer such a question, we must know what is the policy objective or no evaluation can be made. Looking at it from the standpoint of cultural economics suggests that the criteria that should be adopted for assessing copyright reform are to be found in cultural policy. I have argued elsewhere that copyright policy must be thought of as part of cultural policy (as it already is in some countries and the trend is increasing); logically, therefore, the objectives of cultural policy - fostering creativity, cultural diversity, freedom of information and expression, broadening audiences for cultural events, etc. should be used to judge whether a reform to copyright law is a welfare improvement or not. Concern with these aspects of 'social' efficiency is surely what marks out the cultural economists from the rest of the profession.

Unlike any other branch of economics (or, as far as I know, of law), cultural economists have tried to understand the role of economic incentives in stimulating artistic supply (whether by authors or performers). Frey is the first economist to have specifically addressed the question of creative motivation (Frey 2000). He distinguished what he calls institutional creativity' from 'personal creativity'; institutional creativity is supposed to be motivated by extrinsic rewards that the market and the state can offer, the market through revenues from ticket sales and the like and the state through measures, such as subsidy. Personal creativity is more closely related to intrinsic motivation, which in its extreme form is the Romantic driven genius pursuing art for art's sake at all

\footnotetext{
${ }^{17}$ Kretschmer (2003) argues that collective rights management is a form of unionization and finds this more convincing that the economic explanation of transaction cost minimization.
} 
costs. Frey's main insight is that there is a 'crowding out' effect when extrinsic rewards inappropriately are applied to intrinsically motivated effort: inappropriate extrinsic reward would either fail to motivate the artist of even be a disincentive to the artist. In Towse (2001b), I extended these ideas by considering whether a balance between intrinsic and extrinsic rewards is achieved through government cultural policies that combine a program of financial subsidies, grants, prizes and honors with copyright law. I suggested that copyright law plays an important role in the balancing act as it provides both intrinsic and extrinsic incentives through the combination of economic and moral rights.

Cultural economics has produced a number of studies of artists' supply behavior which in general show the following characteristics: that artists are mostly self-employed, multiple job-holders working in two separate labor markets, arts (and arts-related; for example teaching their art) and non-arts; they derive positive utility from arts work and seem to prefer it to leisure; the individual nature of artistic creativity and talent means artists cannot easily be substituted one for another, and that the goods and services they produce are also not easily substituted. Throsby (2001) has provided some evidence that artists do work partly for the money and that their labor supply responds positively to financial rewards, though intrinsic motivation and preference for arts work is strong. The elasticity of artists' labor supply is clearly important information for any policy-maker wishing to stimulate creativity. This is a topic that should also be investigated to test the incentive offered by changes to copyright law.

It is frequently suggested by the advocates of the WPPT that the introduction of individual exclusive rights for performers will lead to higher earnings for them. ${ }^{18}$ However, despite the frequently repeated rhetoric of copyright advocates, we have very little hard evidence about the effect of copyright on artists' earnings. Copyright enables authors and performers to earn from their investment but it does not ensure they do so and how much they earn from royalties depends on market forces. What seems to be the case is that the economic organization of the cultural sector plays a more important role than does copyright law in the contracts between artists and firms in the cultural industries (Caves, 2000). ${ }^{19}$ The more powerful the firm is in the industry, the greater is its bargaining power and the relatively weaker the performer is when it comes to striking an individual bargain. Except in the rare case of the superstar, the business side has the upper hand (Caves, 2000). The earnings and the incentive to artists from copyright are

\footnotetext{
18 These advocates include WIPO, industry pressure groups and artists' organizations.

${ }^{19}$ That does not mean that copyright has no effect - we do not know since it is ever present. Research on the so-called 'counterfactual' - the way markets would work absent copyright can only be done in industries in which intellectual property rights are weak or non-existent.
}

Review of Law \& Economics, ( 2007 by bepress 
therefore weakened by the market structure in the cultural industries, which are mostly oligopolies (Bettig, 1996). The market structure of the cultural industries is thus an important aspect of the economics of copyright. The Internet is changing this situation to some extent, though most cultural economists think the scope for 'self-promotion' is limited to artists who have already made a name for themselves (Farchy and Ranaivoson, 2005).

Once economic rights have been assigned, the performer has little residual control over their exploitation (unless moral rights are infringed). When the record label decides to delete their works from the catalogue, performers can rarely do anything to stop them: the copyright may last 50 years but the shelf life of the recording it is more likely to be 5 years or less. The discussion so far has focused on the question whether there are economic benefits to performers from the introduction of the individual exclusive right mandated by the WPPT and that seems far from sure or even likely. (Of course, they also acquire moral rights, which they value). Social benefits, however, comprise those to the whole society - the users of copyright material as well as the performers. One of the chief benefits to users is believed to be that DRM (Digital Rights Management) offers the prospect of cheap and easy licensing and distribution arrangements for authors' and performers' works (though as yet there is no standard DRM system) and this being strongly promoted by WIPO and the EU in the belief that it will encourage online supply. Furthermore, it is also held that DRM can obviate the need for collecting societies and CRM and that the possibility for individual performers of exercising their own rights will curtail the monopoly powers of collecting societies.

Now, it is certainly the case that managing rights digitally (one of the meanings of $\mathrm{DRM}^{20}$, once up and running, would cut out some of the cumbersome costs of collecting license fees, distributing royalties and monitoring use but it would not and could not eliminate them entirely. Databases have to be kept up to date and performers kept in touch with. Moreover, a DRM system is itself not costless and it is an open question who will pay the costs of any digital encryptment or watermarking system. I have so far not seen any cost figures included in any of the DRM discussions.

However, any database has a specific economic characteristic (Shapiro and Varian, 1999). This is the type of monopoly is known as 'natural monopoly' and is regarded by economists as socially efficient if in the hands of non-profit organizations or regulated by the government so as to prevent excessively high prices. High initial set-up (fixed) costs combined with a low marginal cost of adding one more user typically results in natural monopoly because it produces

\footnotetext{
${ }^{20}$ Another is the management of digital rights.
} 
the service at the lowest possible average cost. This is the economic explanation for the prevalence of the monopoly that the collecting societies have. It is therefore no surprise to find that in the UK, where all the collecting societies have been allowed to develop spontaneously, each has a natural monopoly over the specific set of rights it licenses. In order to distribute on an individual basis, all collecting societies need a database of information on members' performances as well as of their contact details. This requirement is a sufficient condition for the development of natural monopoly in the provision of royalty collection services.

It is ironic that now the EU, which so favored collecting societies in the Rental Directive to the point of requiring them to be specially set up to administer equitable remuneration for public performance and rental rights for performers, should now make the collecting society monopolies, in particular those in the so-called 'Santiago Agreement', the target of attention for anticompetitive practices. ${ }^{21}$ It is not at all obvious that performers can meaningfully exercise their individual rights without a collecting society and those monopolies are likely to persist for reasons of economic efficiency. What may be a more significant barrier to the development of one-stop DRM are the legal constitutions of the different national collecting societies that are protected from market forces. The EC's policy on collecting societies should distinguish administrative efficiency in governance from economic efficiency in producing the service of rights management. The Single Market pan European one-stop shop could well lead to an even bigger natural monopoly.

Another issue in relation to the overall welfare benefits of individual performers' rights is where does the money come from? As Taylor and I pointed out in relation to the Rental Directive, if performers are going to benefit financially from their new rights, either another group of claimants will get less or the public will pay more or profits of companies in the cultural industries will be reduced (Towse, 2001a). The only possible source of a 'free lunch' is growth in the demand for their services, for example, for licensed online music. It is well known that authors' societies and representatives worry that any 'bounty' to performers is likely to be financed by a reduction in their share of the spoils. It remains to be seen whether in fact performers do earn more as a result of this change in the law. If they do not, the hyped social benefits of DRM etc. would in fact be being obtained at the expense of performers.

All things considered, therefore, it would appear that the introduction of individual exclusive rights for performers is not an unambiguous welfare

\footnotetext{
21 The agreement made in 2001 between 16 of the European authors' collecting societies to grant a 'one-stop shop' copyright license to online commercial users.
}

Review of Law \& Economics, () 2007 by bepress 
The Singer or the Song? / 763

improvement. Until there is more empirical evidence of costs and benefits, the jury must remain out on this one.

\section{IS COPYRIGHT LAW THE BEST WAY OF ACHIEVING THE POLICY OBJECTIVES?}

Finally, we should ask what other policy tools there are for achieving the same policy objectives. That is a typical question economists ask about any policy but one that lawyers appear to find difficult to contemplate.

It was perceived by economists early on that enacting copyright law was not the only means of encouraging the creation of and access to works of literature, art and music since artists could also be rewarded by prizes or other forms of state patronage (nowadays, subsidy and honors) or, indeed, by private patronage of one type or another. This view was standard among the few economists who wrote about copyright until the 1960s and it repeatedly reappears. ${ }^{22}$ Such patronage directly benefits the artist, in contrast to the copyright system that works indirectly via the cultural industries and their reliance on success in the marketplace. This is not the place to rehearse all the arguments for and against subsidy to the arts but it is worth stating that there are some good reasons for state subsidy to the arts and heritage. ${ }^{23}$ However, individual artists receive a very small proportion of subsidy, though it must not be forgotten that most performers, at least in Europe, are trained in government financed music and drama colleges and universities offering performance courses (Towse, 1996).

"The principle of copyright is this. It is a tax on readers for the purpose of giving a bounty to writers ... I admit, however, the necessity of giving a bounty to genius and learning." Macaulay, $1841 .^{24}$

This famous quotation from Macaulay demonstrates the clear perception that copyright is a system for getting the consumer (the 'reader') to pay for the incentive to the author. That is an important point for the choice of policy measures for achieving cultural objectives; however, that aspect is not often discussed. By contrast, the alternative incentive system of subsidy to artists is

\footnotetext{
${ }^{22}$ For a brief review of the development of the economic analysis of copyright, see Towse (2004). A full scholarly exposition is to be found in Hadfield (1992). A recent reappearance of this view is to be found in Shavell and van Ypersele (2001).

23 That is not to say how much should be spent or that the distribution of subsidy follows economic rules. See, for example, Peacock (1993).

${ }^{24}$ Quoted in Hadfield (1992).
} 
financed by taxpayers, only some of whom are consumers of the goods and services whose production they pay for. Those who are skeptical of subsidy to the arts may well bear this point in mind (and mutatis mutandis, copyright skeptics might do so too!). Regulation by copyright law and a policy of subsidy, even if they both produced the same incentive benefits, spread costs differently.

\section{CONCLUSION}

In general, economists favor establishing individual waivable property rights for efficiency reasons but only in conditions in which they can be exercised equitably. The problem for performers (and creative artists too) is that they do not have a 'level playing field' unless the firms in the cultural industries compete for their services or are effectively regulated. Reducing the power of collective action for performers will likely reduce their ability to bargain for acceptable royalty rates and hence also reduce the economic incentive to create copyrightable works. Composers of songs need singers to perform them because together they create value. Each needs the other mutually. Even though the value chain starts with the composer, the unsung song has little value. Thus there is an economic case for performers' rights.

So, what can we conclude from the foregoing analysis about the underlying motives for the extension of performers' rights? Does the change reflect the growing social adulation of the talent of the performer, even of non-featured artists, as existing side by side with the genius of the author/composer? Or do changes in performers' rights just reflect the new technological possibilities offered by digitalization? Is it that DRM points to the possibility of administrative efficiency by reducing transaction costs, always considered desirable on the grounds that they are a dead weight loss of economic welfare? Might it not be that copyright law and with it performers' rights are anyway motivated by equity rather than efficiency considerations as suggested by some economists?

These broad considerations, however, should not mask more practical questions that are also important in assessing the likely net benefits to performers of having individual exclusive rights. How are such rights to be administered? We saw above that while featured performers typically negotiate individual royalty contracts for sales and therefore receive their royalty payments direct from the publisher (or record label), non-featured musical performers until now have been paid a flat fee for making the sound recording. Both get remuneration payments for secondary use that are collected and distributed by collecting societies. How will these arrangements alter with the new rights? A lot would seem to depend upon whether individual performers are able to collaborate in order to negotiate

Review of Law \& Economics, ( 2007 by bepress 
the rate of payment and collection of income due to them. In some countries, collecting societies are able only to administer collective rights, not individual ones. Moreover, the view is developing in the EU that collecting societies are anticompetitive and are holding-up online delivery of music (possibly also of images and other such goods). How will DRM impinge on the administration of copyrights - will it cut out the need for collecting societies or instead make them all the more necessary if transaction costs are high? Allied to these questions are those about how it is envisaged the cultural industries will respond to digitalization, for example, will having an individual making available right empower performers to release their own work over the internet? Or will it just make them more vulnerable by reducing their bargaining position with a record label? Will record labels even survive in the online era? These are all question to which we do not yet know the answers.

\section{References}

Bettig, Ronald. 1996. Copyrighting Culture. Boulder: Westview Press.Caves, Richard. 2000. Creative Industries. Cambridge, MA: Harvard University Press.

Christiansen, Rupert. 1984. Prima Donna: A History. London: Penguin Books.

Coase, Ronald. 1979. "Payola in Radio and Television Broadcasting" 22 Journal of Law and Economics 269-328.

Cornish, William. 2003. "The Author as Risk-Sharer," 26(1) Columbia Journal of Law and the Arts 1-16.

Ehrlich, Cyril. 1985. The Music Profession in Britain since the Eighteenth Century. Oxford Clarendon Press.

Einhorn, Michael. 2003 "Music Licensing in the Digital Age" in R. Towse, ed. Copyright in Cultural Industries. Cheltenham, UK and Northampton, MA: Edward Elgar.

Farchy, Joelle, and Heritiana Ranaivoson. 2005. "DRM and Competition: The Consequences on Cultural Diversity for the Case of the Online Music Market," Montreal, SERCI conference, www.serci.org.

Frey, Bruno. 2000. Arts and Economics. Berlin, Heidelberg: Springer.

Gallagher, Thomas. 2003. "Copyright, Compulsory Licenses and Incentives," in R. Towse, ed. Copyright and the Cultural Industries. Cheltenham, UK and Northampton, MA: Edward Elgar.

Hadfield, Gillian. 1992. "The Economics of Copyright: An Historical Perspective," 38 Copyright Law Symposium 1-46.

Kretschmer, Martin. 2003. "Copyright Societies Do Not Administer Individual Property Rights: The Incoherence of Institutional Traditions in Germany and the UK," in R. Towse, ed. Copyright in Cultural Industries. Cheltenham, UK and Northampton, MA: Edward Elgar. 
. 2005. "Artists' Earnings and Copyright: A Review of British and German Music Industry Data in the Context of Digital Technologies," http://www.firstmonday.org/issue10_1/kretschmer.

Landes, William, and Richard Posner. 1989. "An Economic Analysis of Copyright Law," 18 Journal of Legal Studies 325-366.

O'Hare, Michael. 1980. "A Malthusian Nightmare for the Composer and His Audience," in W. Hendon, J. Shanahan and A. MacDonald, eds. Economic Policy for the Arts. Cambridge, MA: Abt Books.

Peacock, Alan. 1993. Paying the Piper: Culture, Music, Money. Edinburgh: Edinburgh University Press.

Reinbothe, Jörg, and Silke von Lewinski. 1993. The EC Directive on Rental and Lending Rights and on Piracy. London: Sweet and Maxwell.

Sand, Katherine. 2003. "Study on Audiovisual Performers' Contracts and Remuneration Practices in Mexico, the UK and the USA," Geneva, World Intellectual Property Organization AVP/IM/03/3A.

Shapiro, Carl, and Hal Varian. 1999. Information Rules. Boston: Harvard Business School Press.

Shavell, Steven, and Tanguy van Ypersele. 2001. "Rewards versus Intellectual Property Rights," 4 Journal of Law and Economics 525-47.

Throsby, David. 2001. Economics and Culture, Cambridge: Cambridge University Press.

Towse, Ruth. 1996. "Economics of Artists' Training," in: V. Ginsburgh and P.-M. Menger, eds. Economics of the Arts. Amsterdam: North Holland. . 1999. "Copyright and Economic Incentives: An Application to Performers' Rights in the Music Industry," 52 KYKLOS 369-390. . 2001a. Creativity, Incentive and Reward: An Economic Analysis of Copyright and Culture in the Information Age. Cheltenham, UK and Northampton, MA: Edward Elgar. . 2001b. "Partly for the Money: Rewards and Incentives to Artists," 54 KYKLOS 473 - 490. . 2004. "Copyright and Economics," in S. Frith and L. Marshall, eds. Music and Copyright, $2^{\text {nd }}$ edition. Edinburgh: University of Edinburgh Press, 54-69. . 2006. "Copyright and Artists: A View from Cultural Economics," 20 Journal of Economic Surveys 567-585. and Christian Handke. 2006. Economics of Copyright Collecting Societies, Spanish Authors' Society (SGAE), Madrid. Available on www.serci.org.

Watt, Richard. 2000. Copyright and Economic Theory: Friends or Foes? Cheltenham, UK and Northampton, MA: Edward Elgar. and Ruth Towse. 2006. "Copyright Protection Standards and Authors' Time Allocation," vol. 15(6) Industrial and Corporate Change 995-1011. Oxford University Press, Available online (as of 31/10/06) at http://www.ingentaconnect.com/content/oup/indcor/2006/00000015/000 00006/art00995.

Review of Law \& Economics, (C) 2007 by bepress 